\title{
LEVEL OF FOREIGN DIRECT INVESTMENTS AND TRANSPARENCY OF POLISH AND GLOBAL REAL ESTATE MARKET
}

\author{
Karolina Czechowska, M.Sc. \\ Department of Investment and Real Estate \\ University of Lodz \\ e-mail: kczechowska@uni.lodz.pl
}

\begin{abstract}
The article aimed to present the dependencies between the transparency of the real estate market and the level of foreign investments realized on it. For developers on the real estate market, a key element, other than potential profits, may be the market's transparency. The main feature of a transparent real estate market is easy access to credible data concerning supply and demand, rent, property prices, transactions, vacant houses and capitalization rates that could be the basis for analysis. Market transparency does not guarantee the success of an investment, but considerably influences investment decisions and the level of risk connected with them.
\end{abstract}

Keywords: global real estate market, real estate market transparency, foreign direct investments on real estate market.

JEL Classification: R30.

Citation: Czechowska K., (2013), “Level of foreign direct investments and transparency of polish and global real estate market", Real Estate Management and Valuation, vol. 21, no. 2, pp. 22-28.

DOI: 10.2478/remav-2013-0013.

\section{Market transparency against specific features of a property}

Compared to other goods, a property is made distinct by its specificity, which in turn stems from its characteristic features. These features make a property a special type of good, difficult to classify in the aspect of typical goods occurring on market, which is reflected in little transparency on the real estate market.

One of the features of a property that greatly influences the level of transparency, where the rights to a property are the subject of turnover and valuation, is its variety. The strong heterogeneity of goods appearing on the real estate market requires an individual approach to a given property and individual valuation. There are no identical properties, therefore the price, rent level or amount of vacant houses depend on the specific features of a certain property, which creates significant difficulties at the stage of determining its market value or market rent level. As a consequence, determining a typical price or a typical rent level for the market seems impossible; therefore, there is no market information that would become the basis for investments undertaken by a typical real estate market participant.

Another feature of property that influences market transparency is stability on the site. This feature creates serious economic impact which is important from the point of view of a market participant (KUCHARSKA-STASIAK 2006 p. 18):

1) The value of each property is a resultant of changes in its environment,

2) Real estate markets are of local character.

Transactions made on the real estate market are of a rather local character. Therefore, without a thorough comparative analysis of a property, they cannot be the source of information on a real estate 
market understood more broadly than locally. Furthermore, supply and demand that shape price on the real estate market are also of local character. They are the result of, e.g., the available real estate resources, the power of competition in a given sector, or the purchasing power of the inhabitants. Stability on the site is strongly connected with the economic features of a property, such as its location. "The result of economic location is the manner in which a property is used (...). As a result, similar properties may have a different manner in which they are used and another value" (cited from KUCHARSKA-STASIAK 2006 p. 22). The significant dependence of property value on location and the manner in which it is used, as well as the frequency of market participants' irrational behavior, all have an impact on the lack of market rationality.

On the basis of the above considerations, it can be concluded that it is impossible for the real estate market to be characterized by the total transparency that is the requirement of a perfect market (where goods are homogenous). The specific features of a property make it impossible to fulfill that requirement. Nevertheless, although the real estate market cannot be fully transparent, individual real estate markets and their sectors may be characterized by variety in their levels of transparency. "Real estate markets are at various stages of development in individual countries. (...) Developed markets are more transparent since new instruments are created that increase the availability of information" (cited from KUCHARSKA-STASIAK 2004 p.127).

\section{Level of transparency of the Polish real estate market in relation to the world}

Market transparency is identified with knowledge about the market, which means that every buyer and seller worldwide is aware of all of the occurring possibilities, products and their prices. The real estate market is characterized by a lack of transparent information regarding it, which results in the fact that the majority of market participants do not have sufficient data concerning the prices of properties at the moment of making a decision about buying - selling, since obtaining it is toilsome and requires knowledge about the market. Furthermore, there are many private transactions on the real estate market, the course and price of which, most of the time, remain secret. The informal character of information and its confidentiality make collecting information about this market difficult and costly (KUCHARSKA-STASIAK 2006 p. 48-49).

The main feature of a transparent real estate market is easy access to credible data concerning supply, demand, rent, property prices, transactions, vacant houses and capitalization rates that may become grounds for analysis. Insufficient transparency of the real estate market makes its valuation significantly more difficult. Data concerning transaction prices and contract conditions is not available to general participants. Yet, the accessibility of transactional data does not determine the level of transparency to a large extent, as the amounts revealed in notarial deeds do not often correspond with the actual price that was quoted while concluding a transaction. Every year, there are more and more reports presenting the analysis of local and national real estate markets. It is hard to assess the credibility of these reports as they do not represent data obtained from the market but merely conclusions drawn on its basis. We do not know which properties were included in the surveys, nor do we know how big the surveyed group of properties or market participants was. In all probability, serious developers entering the Polish real estate market do not take decisions concerning investments on the basis of generally available reports of questionable credibility. Carrying out a survey by a professional company operating on the real estate market is expensive but provides the developer with an image of the market that is not seen by its other participants; this gives him greater possibilities to successfully carry out an investment and obtain a planned rate of return.

Figure 1 presents images of the twenty-five most transparent of real estate markets worldwide according to the Global Real Estate Transparency Index (the lower the index value, the higher the market transparency).

Poland is 19th on the list (out of a total of 97 countries) of a worldwide real estate transparency ranking. It describes the Polish real estate market as transparent, which means there is information flow and its participants have access to market data. The classification presents ten of the most transparent real estate markets, among which the leading positions are taken by the United States, Great Britain, Australia, Holland and New Zealand.

Figure 2 presents the transparency of the European real estate markets according to the Global Real Estate Transparency Index. Among the European real estate markets, Poland is $13^{\text {th }}$ on the list. The following countries are included among those considered to be highly transparent: Great Britain, 
Holland, France, Finland, Sweden and Switzerland. Markets characterized by the lowest level of transparency are the Belarussian (non-transparent) and Serbian (with low level of transparency) markets, whereas eastern European real estate markets were described as medium-transparent.

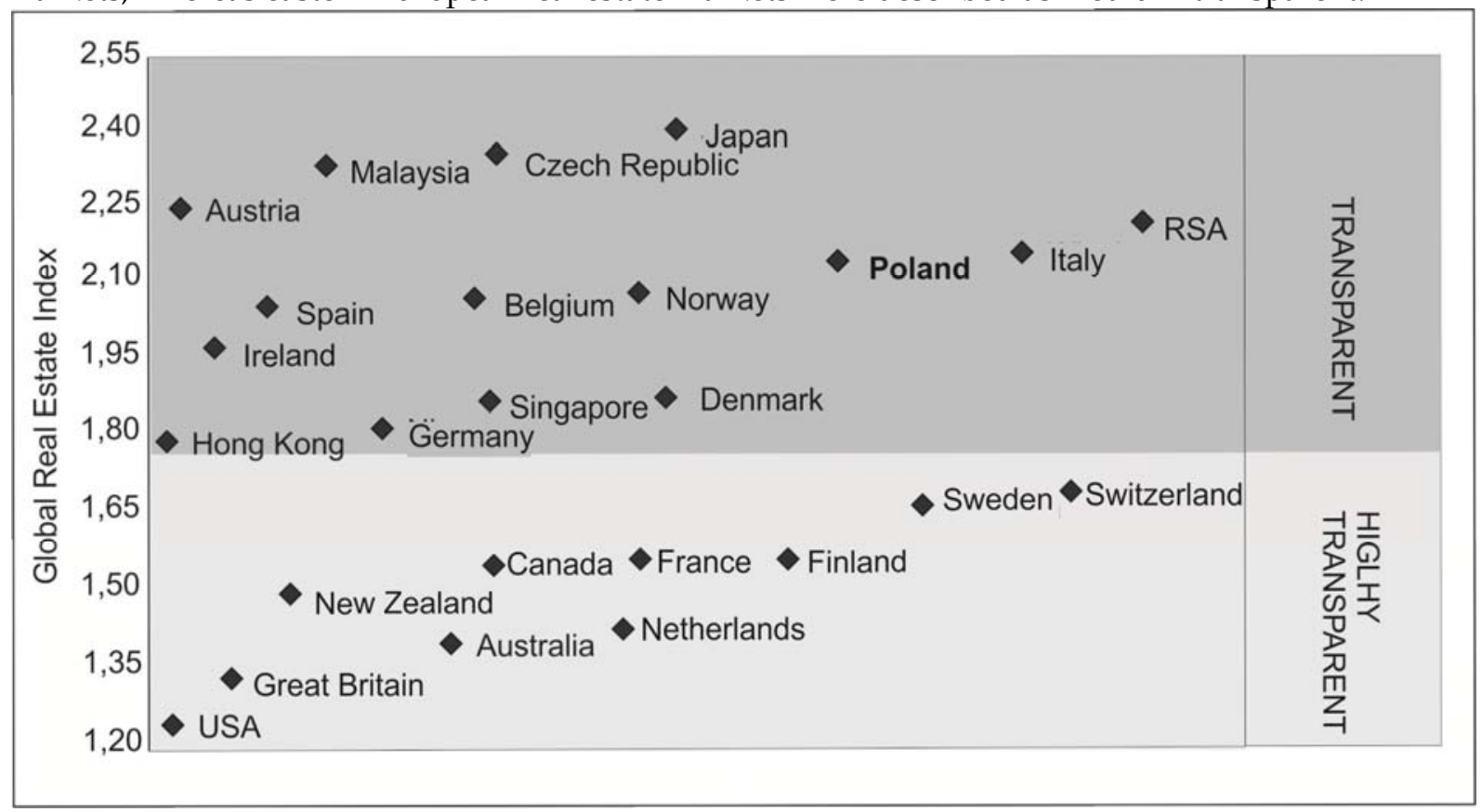

Fig. 1. 25 real estate markets worldwide characterized by the highest level of transparency. Source: prepared by the author on the basis of Real Estate Transparency (Back on Track, 2012, Global Real Estate Transparency Index, Jones Lang LaSalle).

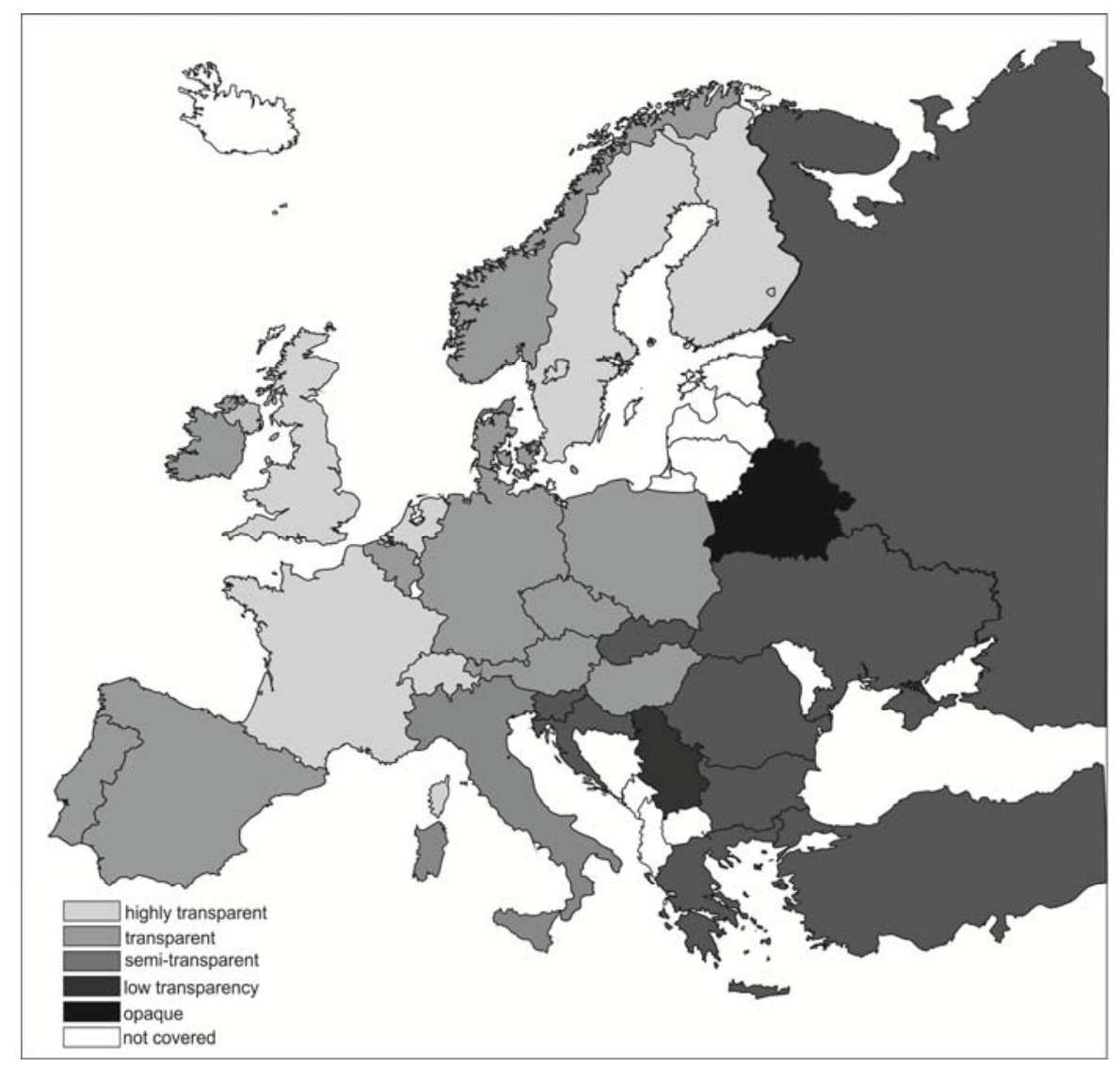

Fig. 2. Transparency of the Polish real estate market in relation to Europe. Source: prepared by the author on the basis of Real Estate Transparency (Back on Track, 2012, Global Real Estate Transparency Index, Jones Lang LaSalle). 
Throughout the years, the level of transparency on the Polish market has undergone regular improvement. Changes in the level of transparency of the Polish real estate market described on the basis of changes in the global transparency index (Jones Lang LaSalle) have been presented in Graph 1.

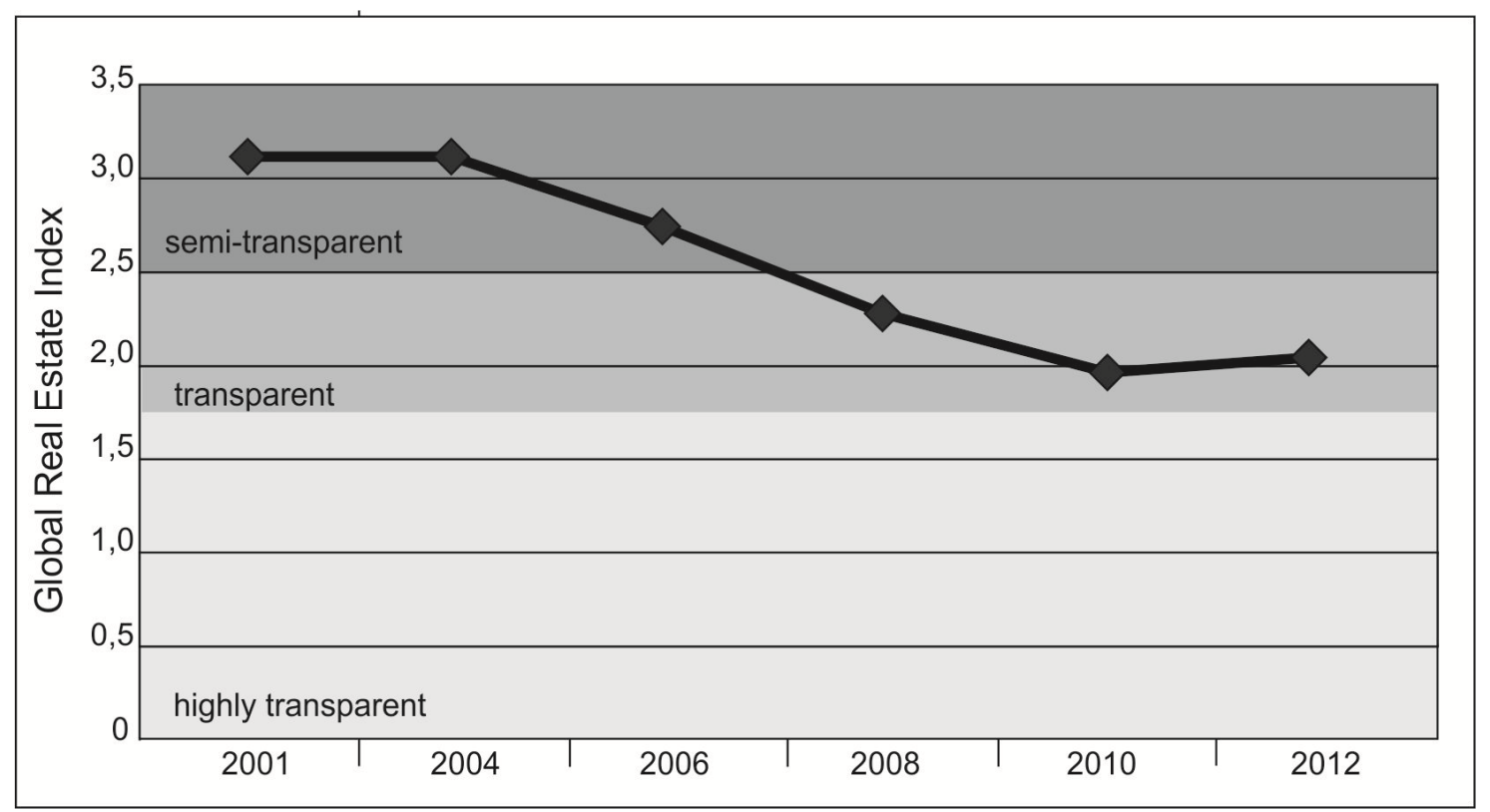

Graph 1. Changes in the level of transparency of the Polish real estate market between 2001-2012. Source: prepared by the author on the basis of the Global Real Estate Transparency Index, 2006, 2010, 2012, Jones Lang LaSalle.

In 1999, the Polish real estate market was described as one with a low level of transparency. Between 2001 - 2006, according to Jones Lang LaSalle, the Polish real estate market was characterized by a middle level of transparency, reaching the level of a transparent market in 2008.

Individual real estate markets worldwide are greatly varied as regards to the level of their transparency. One attractive strategy of increasing the effectiveness of real estate markets characterized by a low level of transparency is entering those markets, using the results of professional market research that are proprietary, provided against payment or generally unavailable, and later introducing clearer business practices that will help increase market efficiency. This would require time-consuming analysis and a constant procedure of noting market data, exact characteristics of supply and demand, and a review of financial information for every investment that took place on the market (GORDON 2000 p. 5).

\section{The level of transparency on a market and the size of foreign direct investment realized in its real estate sector}

Domestic markets once dominated by local entrepreneurs have been transformed into international ones and opened their doors to foreign developers. In the era of advancing globalization and economic integration, worldwide trade and capital flow increase significantly. Freedom of capital flow, technological advancement, the quick transfer of innovation and development of transport and communication increase the role of foreign direct investment (FDI). Nowadays, it is assumed that entrepreneurship requires well-formulated principles and rules that transparently describe ownership and lower the cost of dispute settlement, rules that increase the predictability of economic interaction and give market participants a certainty that they will be protected from potential abuse. These regulations should be effective, simple in realization and available for everyone (Doing business in a more transparent world, 2012 p. 7). Due to the specific features of property, such as stability in the site, the real estate market is particularly sensitive to institutional changes and experiences the weakness of the institutional system in a given country or region. Until recently, a result of that may have been the strong dominance of the real estate market by local investors (EICHHOLTZ, GUGLER, KOK, 2010 p. 2).

From the developer's point of view, the high transparency of a given market is a signal that this 
market is mature and characterized by a lower risk level, with delays or drastically increasing costs occurring much less frequently. High market transparency allows one to compare the costs of land purchase and construction, as well as the rent level, available tax relief and other parameters relevant for developers. The availability of market data in the form of statistics allows developers to carry out the evaluation of an investment's efficiency and valuate the future rate of return. Moreover, free information flow significantly intensifies the decision process. Highly transparent markets are characterized by a lower risk level regarding investment flow and the barriers of entering or leaving a market are weaker. Additionally, less transparent markets, from the viewpoint of a developer, require using the services of professional real estate market advisors or initiating co-operation with local partners. On the other hand, developers do take the risk of entering markets that are not so transparent, where they can receive a risk bonus in the form of a much higher rate of return on their investment (JONES LANG LASALLE 2010, p. 20-21).

Investing in various regions of the world ensures the additional diversification of the investment portfolio. It needs to be remembered that the real estate business is of local character and cash flow generated by it is dependent on the local economy. Therefore, the time and nature of the real return of capital invested in property will vary and depend on the conditions in a given country or region (BRIDDELL, 2010 p. 1). On less transparent markets, foreign investors have a certain advantage over local ones. They may use the services of professional real estate advisors and purchase reports concerning the market so that they have the same level of information as its local participants. However, in addition to this, overseas developers frequently look at a given real estate market from a global perspective, often invisible to those operating on the local market.

Foreign direct investment located in the property sector brings many benefits but also creates additional risk connected with the possibility of rapid change occurring in the size of the located capital, as a result of which great destabilization on the real estate market may take place and, in consequence, affect even the whole economy. In Table 1a, the construction sector ratio is presented as a percentage together with the property service in foreign direct investments coming into Poland between 1996 - 2011.

Table 1

Construction sector ratio together with the property service in foreign direct investments coming into Poland between 1996 - 2010.

\begin{tabular}{cccc}
\hline Year & $\begin{array}{c}\text { \% ratio of the real } \\
\text { estate sector in } \\
\text { FDI }\end{array}$ & Year & $\begin{array}{c}\text { \% ratio of the real } \\
\text { estate sector in } \\
\text { FDI }\end{array}$ \\
\hline 1996 & 2.19 & 2004 & 6.19 \\
\hline 1997 & 1.32 & 2005 & 5.25 \\
\hline 1998 & 1.82 & 2006 & 13.24 \\
\hline 1999 & 2.00 & 2007 & 11.90 \\
\hline 2000 & 4.71 & 2008 & 11.22 \\
\hline 2001 & 4.28 & 2009 & 5.45 \\
\hline 2002 & 5.89 & 2010 & 32.98 \\
\hline 2003 & 7.76 & 2011 & 4.88 \\
\hline
\end{tabular}

Source: prepared by the author on the basis of: Foreign direct investment between 2001-2010 - general trends. 2011. Ministry of Economy, Department of Analyses and Forecasts, Warszawa, Foreign direct investments in Poland, statistical indices NBP 2010, 2011, 2012.

Even though there was more foreign capital coming into Poland in form of foreign direct investments between 2006-2008, the highest ratio of the real estate sector in foreign direct investment was noted in 2010, when FDI in Poland dropped to $36 \%$ as compared to 2009, when the ratio of the real estate sector increased to $32.98 \%$. This indicates a significant role of the real estate sector in attracting foreign capital. However, one needs to keep in mind that the inflow of additional capital changes the relation between supply and demand and hence, also influences the investment decisions of other market participants.

Recently, the Polish economy has drawn much foreign capital, a part of which was located in the real estate market. The inflow of foreign direct investment to the Polish property sector in relation to 
the level of transparency on the market between 2001 - 2011 has been presented in Graph 2.

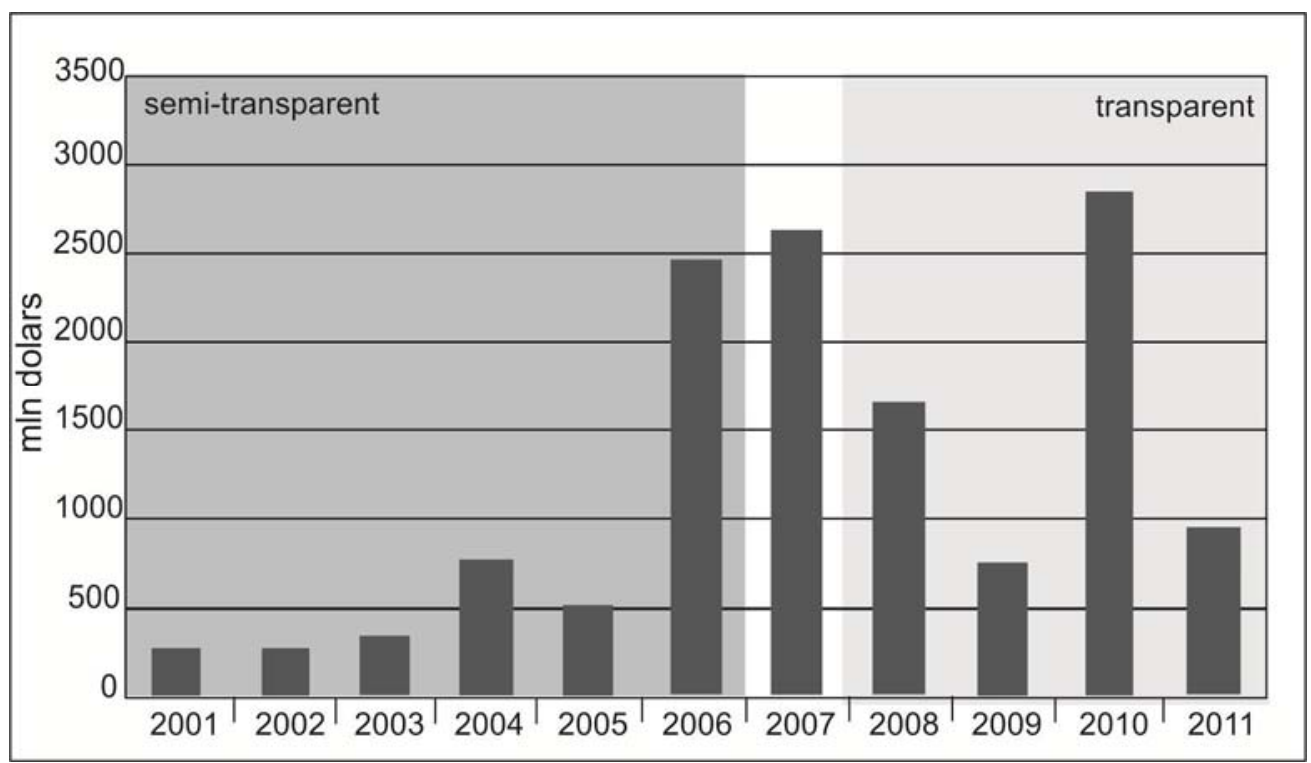

Graph 2. Transparency of the Polish real estate market and the inflow of foreign direct investment to the Polish property sector between 2001-2011. Source: prepared by the author on the basis of Real

Estate Transparency, Back on Track, 2012, Global Real Estate Transparency Index, Jones Lang LaSalle,

Foreign direct investment between 2001- 2010 - general trends, 2011, Ministry of Economy,

Department of Analyses and Forecasts, Warszawa, Foreign direct investments in Poland, statistical indices NBP from 2003 to 2012.

The most foreign capital in the form of foreign direct investment funded the Polish property sector in 2012 (over \$2.9 b), in 2007 (almost \$2.7 b) and in 2006 (over \$2.5 b). Despite differences in the transparency of Polish real estate market in 2006 (medium-transparent) and 2010 (transparent), the inflow of foreign direct investment to the property sector did not differ significantly. This is grounds to conclude that in the case of the Polish real estate market, its transparency was not a key element considered by foreign developers while making decisions. Despite the weak real estate market transparency in 2006, foreign developers still invested a large amount of capital - much larger than in 2008 and 2009 when the Polish market was characterized by a much higher level of transparency.

\section{Summary and conclusions}

High market transparency makes it much easier to make rational investment decisions. On the other hand, in many cases, developers invest their capital in property basing cost effectiveness on the value of an individual property, treating its potential as the key factor and considering it to be even more important than the available data on the market; moreover, they are willing to take the risk that result from low cost effectiveness, provided there is a possibility of gaining a bonus for that risk in form of a higher rate of return. "There is 'inner' information that appears on property market - there are those who are better and worse informed, with majority of the latter" (cited from KUCHARSKA-STASIAK 2006 p. 70). Difficulties in obtaining credible information about the market create the possibility of gaining an advantage on the market and realizing profitable property investments for experienced developers who are willing to take that risk.

On the basis of the above considerations, it can be concluded that high market transparency is not a necessary factor from the point of view of foreign investors. Frequently, it is other parameters that do much more to draw developers as they create possibilities that do not exist on property markets with a high level of transparency. Market transparency is much more important for entities investing in properties indirectly. Appropriate market transparency and the proper valuation of property assets that constitute paper securities for advanced financial products may bring both social and economic benefits in the form of lowering the probability of the occurrence of financial crises in the future (Policy Framework for sustainable real estate markets, 2010, p. 25). 
All around the world, great success is being noted in carrying out real estate market research and introducing procedures of fixed trading in those markets. The good news is that, once undertaken, actions aimed at increasing effectiveness are hard to stop. Not every market will open up to new developers' requirements in the same way, but those that do should focus on market areas that are of key importance from the viewpoint of the developer (GORDON 2000 p. 5).

\section{Bibliography}

Bezpośrednie inwestycje zagraniczne w latach 2001-2010 - ogólne tendencje, 2011, Ministerstwo Gospodarki, Department Analiz i Prognoz, Warszawa.

BRIDDELl E. T., 2010, A Guide to Global Real Estate Investment Options, BNY Mellon Asset Management.

Doing business in a more transparent world. Comparing regulation for domestic firms in 183 economies, 2012, a copublication of the World Bank and The International Finance Corporation, Washington D.C.

EichOlTZ P., GuglaR N., KOK N., 2010, Transparency, Integration, and the Cost of International Real Estate Investments, J Real Estate Finan Econ, SPRINGER.

KUCHARSKA-STASIAK E., 2006, Nieruchomość w gospodarce rynkowej, Wydawnictwo Naukowe PWN, Warszawa.

KUCHARSKA-STASIAK E. POD RED., 2004, Zachodnie rynki nieruchomości, Twigger, Warszawa.

Mapping the world of Transparency. Uncertainty and risk in real estate, 2010, Jones Lang LaSalle, NCREIF Capital Markets Symposium, NCREIF Academy.

Policy Framework for sustainable real estate markets, 2010, United Nations Economic Commission For Europe (UNECEF), Working Party on Land Administration (WPLA), Real Estate Market Advisory Group (REM), Geneva.

Real Estate Transparency. Back on Track, 2012, Global real Estate Transparency Index, Jones Lang LaSalle.

Real Estate Transparency Index, 2010, Global real Estate Transparency Index, Jones Lang LaSalle.

Real Estate Transparency Index, 2006, Global real Estate Transparency Index, Jones Lang LaSalle.

GORDON J. N., 2000, International Transparency in real estate marklets, Zagraniczne inwestycje bezpośrednie w Polsce, aneksy statystyczny NBP od 2003 do 2012 r., Warszawa. 